\title{
Nutritional challenges in children and adolescents with Down Syndrome
}

Marianne Nordstrøm ${ }^{1,2,3}$, Kjetil Retterst $\varnothing 1^{1,4}$, Sigrun Hope ${ }^{5}$, Svein Olav Kolset ${ }^{1,6}$

${ }^{1}$ Department of Nutrition, Institute of Basic Medical Sciences, University of Oslo, Oslo, Norway

${ }^{2}$ Frambu Resource Centre for Rare Disorders, Siggerud, Norway

${ }^{3}$ Unit for Inborn and Hereditary Neuromuscular Disorders, Department of Neurology, Oslo

University Hospital, Oslo, Norway

${ }^{4}$ Lipid Clinic, Oslo University Hospital, Oslo, Norway

${ }^{5}$ Department of Neuro Habilitation, Oslo University Hospital, Oslo, Norway

${ }^{6}$ Corresponding author: Department of Nutrition Institute of Basic Medical Sciences

University of Oslo, Norway 0316 Blindern, Oslo Email: s.o.kolset@medisin.uio.no

The Lance Child and Adolescent Health: https://www.thelancet.com/journals/lanchi/home

DOI: $\underline{10.1016 / S 2352-4642(19) 30400-6}$ 


\begin{abstract}
Several features and comorbidities in DS have nutritional implications and consequences, which needs to be addressed in further detail. In this review, we searched and assessed the literature from year 2000-2019 and found in total 57 nutritionally relevant articles.

In infancy and early childhood, children with DS have high risk of oral motor difficulties and pharyngeal dysphagia with aspiration, which requires systematic attention. To improve nutritional status in children with underweight and clinical signs of feeding problems further evaluation of underlying causes is required. Clinical interventions should promote swallowing safety and development of feeding abilities.

Already from 4-5 years of age overweight may become a concern. To prevent disease later in life, there is an urgent need for more research on nutritional aspects in prevention and treatment of obesity for adolescents with DS. The present review did not find any data to support the use of dietary supplementation except when deficiency is documented. In addition, the literature presented clearly documents the need for more research using larger study samples, and control groups, addressing important nutritional challenges in children and adolescents with DS.
\end{abstract}




\section{Introduction}

Adequate nutrition is fundamental for growth, development and well-being of all children. In children with Down syndrome (DS) attention to nutritional intakes and status is important as several features and comorbidities have nutritional implications and consequences (Table 1). To promote evidence based nutritional care from health professionals there is need to address nutritional issues in this patient group.

DS is caused by trisomy of the whole or a part of chromosome 21. It is the most common cause of mild to moderate intellectual disability, affecting about 1:800-1:900 live born, but with variation between countries due to differences in maternal age and prenatal screening (1, 2). Children with DS have characteristic phenotypic features, psychomotor developmental delay, and increased rate of congenital malformations (3). On individual level children with DS show large variability as some have mild symptoms and complications, whereas other are more severely affected. This also applies to the risk of nutritional related health problems.

When assessing nutrition in DS it is important to be aware of health conditions that may influence nutritional care and dietary advice. Congenital heart defects are found in approximately $45 \%$ of the children, most often atrioventricular septum defect and ventricular septum defect (4). Gastrointestinal tract anomalies such as duodenal atresia, Hirschsprung's disease and anorectal malformations occur in 4-6\% (5-7). The incidence of celiac disease is increased in DS and been shown to vary between different countries, but a recent metaanalysis show numbers in the range of 5-6\% compared to $0.5-1 \%$ in the general population (8). In addition, these children also have increased risk of comorbidities such as hypotonia and orofacial dysfunction that may affect the child's feeding ability (9) and thyroid disease, as hypothyroidism (10), with potential to influence energy metabolism. Autoimmunity is increased in DS (11) and in a national Danish cohort of children with type 1 diabetes, the prevalence of DS was 4-fold increased compared to the general prevalence of DS in Denmark (12).

Guidelines have been developed to facilitate health supervision in children with DS (13). These describe nutrition and physical activity as areas that require ongoing assessment throughout childhood to achieve and maintain appropriate weight (13). As a group, children with DS have elevated risk of feeding problems and obesity $(14,15)$. It is well known that childhood establishment of healthy eating habits is important for prevention of disease later in life and increasing longevity in DS is likely to lead to increased manifestation of lifestyle 
associated diseases (16). Obesity is known to be associated with type 2 diabetes, cardiovascular disease and some types of cancers. In DS obesity is also linked to reduced functional abilities and activities of daily living (17). Few previous reviews have been conducted on nutritional aspects in this vulnerable group. To further describe and explore nutritional challenges in youth with DS, we searched and assessed the literature with the objective to describe feeding abilities, nutritional intakes and nutritional status in DS and to provide some suggestions for relevant clinical measures and interventions.

\section{Search strategy and selection criteria}

Ovid medline was searched for articles using the following search terms "Down syndrome" AND ("nutrition", "nutritional", "feeding", "diet" OR "dietary") and we limited our search to articles published in English from January 2000 to August 2019. This period was chosen to be relevant for current care practice, due to the increased survival rate of children with DS born with congenital malformations and improvements in medical and nutritional treatment during the last decades. The search identified 351 articles. Titles and abstracts were assessed for studies in children and adolescents with DS. We included original studies using various descriptive and intervention designs, and most recent nutritionally relevant review articles (Figure 1). Case-reports and studies in animal models were excluded. In total 57 articles were identified. Supplementary search was performed for identification of diagnosis-specific growth curves.

\section{Infancy and breastfeeding}

Most neonates with DS are offered human milk but the proportion and duration of exclusive breastfeeding are reduced $(5,18)$. The total number of children with DS exclusively breastfed varies between countries from $43 \%$ in Italy (18), to $48 \%$ in the Netherlands (7), $55 \%$ in Israel (5) and $63 \%$ and $67 \%$ in Mexico (19) and Saudi Arabia (20), respectively. In the Italian study, including 560 children with DS, the mean duration of breastfeeding was 54 days (SD 111) compared to 165 days (SD 120) in controls (18). Congenital malformations, prematurity, perceived milk insufficiency, suckling difficulties and maternal depression were factors found to limit breastfeeding $(5,18,20,21)$. Furthermore, neonatal hospital admission confer risk of reduced breastfeeding.

In children 0-3 months of age most parents describe prolonged meals (30-60 min) (21). This could be exhausting for both the child and parents. In this period, it is normal for parents to 
experience stress and difficult emotions such as shock and grief related to having a child with DS. Indeed, frustration and depression in mothers have been reported to be an important factor for termination of breastfeeding $(18,20)$.

Although some babies with DS in the beginning do struggle with feeding, it is important to recognise that most babies and mothers with time and guidance from competent health professionals can make the transition to breastfeeding (22). Thus, family-oriented support may enhance breast feeding practice, early parent-child bonding and improve long-term child outcomes $(22,23)$.

\section{Feeding and swallowing problems}

Feeding abilities are often reduced in children with DS and approximately 55-60\% have feeding and swallowing problems $(24,25)$. For a period, typically from 0-3 months, $13-40 \%$ of the children require nasogastric tube for adequate nutrition $(5,21,26)$, whereas $2-5 \%$ of the children receive gastrostomy $(5,21)$. Children with atrioventricular septal defect are more likely to need gastrostomy (27).

For early detection of feeding problems, all children should be clinically screened for feeding and swallowing concerns. Structural and functional oropharyngeal abnormalities, immature neuromotor development and hypotonia leads to poorer neuromotor function and are associated with sucking problems, poor lip seal, slow sucking, dysphagia and aspiration (9, $21,25,28)$. Oral motor difficulties have been described in $64 \%$ and pharyngeal dysphagia with aspiration in $57 \%$ (25). In the cases where aspiration was detected, almost all (90\%) aspirated silently. A recent study found aspiration in $32 \%$ of infants evaluated before 6 months of age, whereas aspiration was detected in $52 \%$ of children between 6-12 months of age (29). In this study, children subjected to swallow assessment after 6 months of age were more likely to have unchanged findings on follow-up, compared to children evaluated before 6 months of age. This suggests that early referral to swallowing assessment may to some extent prevent complications due to swallowing abnormalities. High rates of pharyngeal dysphagia was also described by O’Neill and colleagues, who found that $58 \%$ of children with DS ( $n=201)$ got this diagnosis after videofluoroscopic swallowing assessment(28). For this reason, we suggest that videofluoroscopic swallowing assessment, should be offered early to children with clinical symptoms during meals $(24,25)$. In children with pharyngeal dysphagia such an assessment should be followed by feeding modification recommendations. Relevant dietary interventions to improve swallow safety, includes thickened liquids (77\%), 
changed feeding procedure to control flow rate or bolus size $(8 \%)$ and in some children $(7 \%)$ no oral intake (25).

Age at introduction to solid food is for most children with DS similar as in typically developed children, with $46 \%$ introduced to solids between 6-9 months and $38 \%$ between 912 months of age (20). Despite this, learning to eat solid foods from the first bits of pureed food and baby cereal to regular table foods is a long process. Development of feeding abilities and self-feeding skills are, as other developmental milestones, often delayed in children with DS $(14,30)$. As the skills required become more advanced, children with DS are increasingly delayed, and the age difference for achievement increases between children with and without DS (30). Indeed, feeding problems may remain as a challenge with predominant problems in oral phase, followed by pharyngeal phase and oesophageal phase in children with DS $2-7$ years of age (14). In the oral phase, immature chewing pattern and poor bolus control are common concerns. In children 1-4 years of age, common difficulties are chewy, firm and gummy/rubbery food texture, whereas creamy, soft and puree texture are often reported to be accepted (31). However, with increased age, also crispy, dry and hard food texture were more likely to be managed by the child (31).

Issues related to dental health are also highly relevant when assessing feeding and swallowing issues in children with DS, as these children have increased risk of dental abnormalities and severe tooth wear $(32,33)$ which also potentially can affect the child's ability to chew. Parents and health professionals should be aware that prolonged bottle feeding and use of pacifier (more than 24 months) have been associated with development of open bite and cross bite (34).

Structural training programs to strengthen oral motor function and adjustment of food consistency are relevant interventions for children with poor oropharyngeal motor abilities (35). Some children (20\%) also have oral sensory processing difficulties $(14,25)$ and can benefit from interventions to address such difficulties. Behaviour typically seen in oral hyposensitivity includes overstuffing of food, foods held in mouth without chewing, drooling or preference of intense flavours. In contrast, behaviours typically seen in oral hypersensitivity are food selectivity regarding texture or temperature, a "picky eater". Preference for selected types of foods were reported as a common food related behaviour in children with DS (36). Despite the fact that children with DS have higher rates of feeding problems and often reduced feeding skills, no correlation between parent reported difficult 
mealtime behaviours and feeding skills was observed (37). In addition, parents of toddlers with DS do not report more challenging mealtime behaviours than parents of typically developed children (37).

\section{Parental feeding practice and eating behaviours}

Reports on parental feeding practice showed that parents had greater weight concern, used more restrictions (36) and less pressure to eat in their feeding practice of their child with DS compared to siblings (38). Similar, among parents of overweight children with DS use of restrictions and monitoring of food intakes was more frequent (39). A total of $57 \%$ of the parents reported that their child with DS frequently continued to eat as long as food remained present (36). The potential impact of parental practice on eating behaviour and risk of overweight in youth with DS has not been properly investigated. Eating behaviour is an important issue to address in future studies as it has potential implications both for young children and in older children related to development of obesity. Eating behaviour is an important issue to address in future studies as it has potential implications both for young children and in older children related to development of obesity.

\section{Nutritional status}

The mean birth weight and birth length is reduced in new-borns with DS, with mean birth weight closer to the mean of unaffected children than birth length (6). Reduced growth rate leading to short stature in adult age is a well-known characteristic of most persons with DS.

Growth charts for persons with DS from birth to 18 or 20 years of age have been developed based on several national cohorts (40-46). Traditionally growth curves may be useful in children to monitor growth and nutritional status. For children with DS diagnosis-specific weight-for-length charts can be used to screen for growth faltering and wasting but may be less precise in determining overweight (40).

As consequence of the increased risk of overweight and obesity, the mean body mass index (BMI) percentile for age of children with DS increases during childhood, when plotted on curves developed for the general population. Based on data from the French DS- cohort (41), mean BMI was at $25^{\text {th }}$ percentile (perc) in girls and boys from 0-1 year. Further, it was at $50^{\text {th }}$ perc in girls at 3 years and in boys at 4 years of age, respectively and thereafter at $75^{\text {th }}$ perc for girls at 5 years of age and boys 12 years of age. In 18 year olds mean BMI was at $80^{\text {th }}$ perc for girls and above $75^{\text {th }}$ perc for boys with DS (41). Therefore, when using DS-specific 
BMI curves it is important to recognize that these only describe the normal distribution of BMI values in the cohort and do not necessarily represent ideal weight status $(40,41)$. Plotting a person on such DS specific curve only provide information about weight status compared to peers with DS and can classify a person with DS to be normal weight, that otherwise, by use of standard curves, would classify as overweight or obese (47). However, due to the shorter stature of individuals with DS, the curves and cut-offs developed for typical children have been found to overestimate obesity and percent body fat as measured by dualenergy X-ray absorptiometry (DXA)(48). Therefore, additional examinations may be required to screen for overweight and obesity and associated health outcomes. Measuring skinfolds at four location (triceps, biceps, subscapular and suprailiac) is an alternative method to assess adiposity, and equations have been developed for children with reduced growth (49). Compared to percent body fat by DXA the reduced growth prediction equation performed well in children with DS (49). Another option may be the use of waist circumference. Strong correlation between waist circumference measures and percent body fat measured by bioelectical impedance (BIA) $(r=0.85)$ has been described in a small study (50). Even though these results indicate that BIA and WC could be promising methods in clinical practise, additional validation is required before this could be recommended.

Prevalence of iron deficiency anemia was investigated in an uncontrolled study of 149 children with DS (0-20 years). This study found that $5 \%$ of children younger than 10 years of age and about $14 \%$ of children 10 years or older had iron deficiency anemia (51). This study further described an association between lower than average hemoglobin and delays in motor milestones as starting to walk after the age of two (51). In contrast, in a larger cohort of 856 children with DS iron deficiency was more common (10\%) in children less than 36 months of age compared to those older than three years (4\%) (52). In this study the use of additional parameters to haemoglobin, like ferritin and red cell distribution width to assess iron status is suggested. High risk of low 25-hydroxy-vitamin D levels compared to controls was found in an Italian study where in total $73 \%$ of the sample $(n=31)$ with DS had vitamin D deficiency (53). These studies suggest that blood tests regarding iron deficiency and vitamin levels may be of clinical importance.

\section{Obesity}

Prevention and treatment of obesity are important issues for youth with DS. In a review addressing overweight and obesity in DS decreased resting energy expenditure, increased 
leptin levels, untreated hypothyroidism, unhealthy diet and low physical activity were described as factors likely to contribute to excessive weight gain (15). In line with this, a more recent study on total energy expenditure using doubly labelled water in nine children with DS (mean 10.0 years, SD 3.9), found that those persons with DS required 500-800 fewer calories per day compared to typically developed children (54). Studies on nutritional intake however, did not find decreased energy intake in children with DS compared to controls, but rather, increased energy intake (55) or no difference in energy intake between children with and without DS (56).

In theory, reduced cognitive abilities may influence food choices and activity levels in children. However, no clear effect of the degree of intellectual disability on nutritional status was found when adolescents with DS and mild or moderate intellectual disability were compared (57). Poor knowledge of healthy foods has been described in children with DS 1118 years of age (58). Even so, an intervention study consisting of 18 -session education program on physical activity, healthy eating and motivational skills, only resulted in a shift towards decreased consumption frequency of sweets, and with no other changes in dietary habits observed (59).

To date, most interventions for obesity have been exercise-based and with mixed and inconclusive effects on weight loss (15). Some studies have however been multicomponent interventions. In a small 6-months nutrition and exercise intervention study ( $n=21)$, no weight loss was achieved in the group receiving 16-session nutrition and exercise education program with individualized diet and exercise plans (60). However, in the group where parents also received education in behavioural strategies, such as diet and activity monitoring, short term goal setting and positive reinforcement, participants lost an average of $2.7 \mathrm{~kg}$. At 1-year follow-up mean weight loss was $2.0 \mathrm{~kg}$ (60). This study points to the possible importance of family-oriented interventions and education on maintenance strategies as possible critical success factor, but needs to be further evaluated in larger samples.

\section{Nutritional intakes and assessments}

Assessment of nutritional intakes is an essential component in prevention and treatment of abnormal weight status and micronutrient deficits. However, few studies have addressed dietary intakes in children and adolescents with DS and no specific dietary pattern in this group have been shown to be associated with increased risk of overweight (15). Intakes below recommended dietary allowances (RDA) of various micronutrients was found in some 
individuals $(55,61)$, and compared to siblings, reduced intakes of protein and certain micronutrients have been documented (56) (Table 2).

Parents of young children are most often able to present a fair picture of their child's typical dietary habits and nutritional intake. Due to the widespread use of dietary supplements in children with DS (62) all assessments of nutritional intakes in this population should include questions about use of herbal and dietary supplements. As children with DS grow older, additional methods may be required to provide adequate dietary data. Technology based methods like image-based mobile food records have been found to be accepted, feasible and promising for nutritional assessment in adolescents with DS $(63,64)$.

\section{Dietary supplementation studies}

Vitamins, minerals and antioxidants from the diet are important cofactors in many biochemical processes throughout the body. To ensure short- and long-term health, most countries have developed recommendations for daily intakes. The study by Reza and colleagues found a positive effect on bone mineral density of exercise with and without intake of calcium and vitamin D from enriched milk. The interventions in this study mimic general recommendations of physical activity and intakes of calcium and vitamin D from foods, and provide some evidence that adherence to these general recommendations also have positive effects on bone health in children with DS (65). Likewise, in the study by Stagi and colleagues, a positive, but inadequate effect was documented by supplementing with 10 $\mu \mathrm{g}$ /day of vitamin D3 in a population with low 25-hydroxy vitamin D status as baseline (53). This study did not investigate total intake of vitamin $\mathrm{D}$ in diets but described reduced intake of vitamin D from fortified milk in the DS-group. The study points towards the importance of adequate intake to prevent low vitamin D status and that adherence to general recommendations may be inadequate in already deficit persons.

The presence of an extra copy of chromosome 21 leads to overexpression of genes located on the chromosome, and further metabolic alterations leading to elevated oxidative stress and abnormalities in zinc metabolism $(66,67)$. This has led to hypothesis that dietary interventions with higher intakes than general recommendations of selected antioxidants, vitamin and minerals in supplements can contribute to normalize biochemical processes, and by this ameliorate the syndromes effect on the nerve system and intellectual ability.

Table 3 summarize the most recent dietary intervention studies and their findings. Although several studies report improvements in biochemical markers, no study have so far been able 
to translate this into improvements in clinical outcomes. An important limitation is that most studies include small samples and do not include any description of clinical outcome measures. The randomised controlled trial by Ellis and colleagues (68) had a stricter study design and included a relatively large sample of infants with DS $(n=156)$ with mean age of 4 months at enrolment. They investigated the effect of antioxidants and folate supplementation and did not find any improvements on biochemical measured oxidative stress or cognitive functions, measured by development of major motor milestones and language development (68). Further, a systematic review from 2002 by Salman did not find evidence of effects on cognitive function or psychomotor development by any combination of supplement with vitamins or minerals (69). No studies on safety of dietary supplements were found and this is a concern, as some of the doses used were high. Gastrointestinal distress was reported as a side effect of dietary supplementation $(62,68)$. No association between use of vitamin supplements and risk of leukaemia has been documented in children with DS (70).

Despite the lack of evidence of effect, the use of various dietary supplementations remains common in children with DS. In a survey with more than 1100 responders from USA, $49 \%$ currently gave or had given their child supplements, where antioxidants and vitamins were the most popular supplement categories (62). On average, the children used three supplements (range 1-18). A total of $87 \%$ of the parents reported improvements in language, immunity and attention. This demonstrates a discrepancy between the scientific literature and parent opinions that needs to be systematically addressed.

\section{Dietary issues related to celiac disease and diabetes type 1}

As previously mentioned, children with DS have increased risk of celiac disease (8) and type 1 diabetes (12). The only available treatment for celiac disease is gluten free diet. In a small study of nine persons with DS diagnosed with celiac disease, at 1-year follow-up clinical improvements in anemia and diarrhea, and improved behaviors with less irritability was observed in persons with good diet compliance (71). Apart from this, no other studies were identified describing aspects related to diets or determinants of diet compliance in children with DS and celiac disease or diabetes.

\section{Limitations and future perspectives}

Research on nutritional challenges in DS is limited with few intervention studies performed. Several studies include small numbers of participants and with wide age distributions and 
inadequate descriptions of health status. In addition, many studies include cohorts followed up at specialist clinics and may therefore be selective populations. There is need for more in depth studies with representative samples and controlled study designs, using cutting edge methods and technologies. This review shows that there is an urgent need for studies addressing energy requirements, nutritional intakes and status that should be the basis for development of targeted randomized clinical interventions. In such studies knowledge about relevant health issues DS in general and nutritional issues in DS in particular, is needed for such studies to be of quality and relevance for medical doctors and clinical dietitians working with this group.

\section{Conclusions}

Increased focus on nutritional measures is important for the health and well-being of children and adolescents with DS. Specific clinical features of DS have nutritional relevance and needs to be addressed systematically. There are different nutritional implications in the various age groups with feeding problem as predominant in the first years of life. In this phase clinical screening for feeding problems and evaluation of children with feeding difficulties and low weight gain is important. Excessive weight gain is a concern for many children with DS already from 4-5 years of age. This calls for early prevention to avoid later disease. The switch between preventing the risk of undernutrition in first year of living and obesity in later years represent a treatment challenge. Clearly, there is a need for more research on nutritional aspects in prevention and treatment of obesity.

\section{Conflict of interest}

The authors declared no conflicts of interest

\section{Contributors section}

Marianne Nordstrøm: Performed literature search and identified relevant articles. Read included studies and drafted the manuscript and tables. Made the figures, finalized draft, and participated in discussions and revision of manuscript. 
Sigrun Hope: Contributed in planning of first draft. Contributed with clinical cases and relevant pathology linked to nutrition. Contributed and commented on first draft and commented on revised manuscript.

Kjetil Retterstøl: Contributed in planning of literature search and the use of selection criteria and first draft, and with clinical examples and relevant pathology linked to nutrition.

Commented and contributed in finalizing manuscript and during revision of manuscript.

Svein O. Kolset: Contributed in planning of literature search and use of selection criteria.

Performed literature searches. Contributed to outline of manuscript and preliminary draft and finalizing of manuscript. Participated in discussions and revision of manuscript. 


\section{References}

1. Loane M, Morris JK, Addor MC, Arriola L, Budd J, Doray B, et al. Twenty-year trends in the prevalence of Down syndrome and other trisomies in Europe: impact of maternal age and prenatal screening. Eur J Hum Genet. 2013;21(1):27-33.

2. de Graaf G, Buckley F, Dever J, Skotko BG. Estimation of live birth and population prevalence of Down syndrome in nine U.S. states. Am J Med Genet A. 2017;173(10):2710-9.

3. Ostermaier KK. Down syndrome: Clinical features and diagnosis [Online database]. UpToDate2019 [updated March 18. 2019; cited 2019 August 13]. Available from: https://www.uptodate.com/contents/down-syndrome-clinical-features-and-diagnosis.

4. Freeman SB, Bean LH, Allen EG, Tinker SW, Locke AE, Druschel C, et al. Ethnicity, sex, and the incidence of congenital heart defects: a report from the National Down Syndrome Project. Genet Med. 2008;10(3):173-80.

5. Ergaz-Shaltiel Z, Engel O, Erlichman I, Naveh Y, Schimmel MS, Tenenbaum A. Neonatal characteristics and perinatal complications in neonates with Down syndrome. Am J Med Genet A. 2017;173(5):1279-86.

6. Mircher C, Toulas J, Cieuta-Walti C, Marey I, Conte M, Gonzalez Briceno L, et al. Anthropometric charts and congenital anomalies in newborns with Down syndrome. Am J Med Genet A. 2017;173(8):2166-75.

7. Weijerman ME, van Furth AM, Vonk Noordegraaf A, van Wouwe JP, Broers CJ, Gemke RJ. Prevalence, neonatal characteristics, and first-year mortality of Down syndrome: a national study. J Pediatr. 2008;152(1):15-9.

8. Du Y, Shan LF, Cao ZZ, Feng JC, Cheng Y. Prevalence of celiac disease in patients with Down syndrome: a meta-analysis. Oncotarget. 2018;9(4):5387-96.

9. Faulks D, Collado V, Mazille MN, Veyrune JL, Hennequin M. Masticatory dysfunction in persons with Down's syndrome. Part 1: aetiology and incidence. J Oral Rehabil. 2008;35(11):854-62.

10. Pierce MJ, LaFranchi SH, Pinter JD. Characterization of Thyroid Abnormalities in a Large Cohort of Children with Down Syndrome. Horm Res Paediatr. 2017;87(3):1708.

11. Gillespie KM, Dix RJ, Williams AJ, Newton R, Robinson ZF, Bingley PJ, et al. Islet autoimmunity in children with Down's syndrome. Diabetes. 2006;55(11):3185-8. 
12. Bergholdt R, Eising S, Nerup J, Pociot F. Increased prevalence of Down's syndrome in individuals with type 1 diabetes in Denmark: A nationwide population-based study. Diabetologia. 2006;49(6):1179-82.

13. Bull MJ, Committee on Genetics. Health supervision for children with Down syndrome. Pediatrics. 2011;128(2):393-406.

14. Anil MA, Shabnam S, Narayanan S. Feeding and swallowing difficulties in children with Down syndrome. J Intellect Disabil Res. 2019;63(8):992-1014.

15. Bertapelli F, Pitetti K, Agiovlasitis S, Guerra-Junior G. Overweight and obesity in children and adolescents with Down syndrome-prevalence, determinants, consequences, and interventions: A literature review. Res Dev Disabil. 2016;57:18192.

16. Englund A, Jonsson B, Zander CS, Gustafsson J, Anneren G. Changes in mortality and causes of death in the Swedish Down syndrome population. Am J Med Genet A. 2013;161A(4):642-9.

17. Nordstrom M, Hansen BH, Paus B, Kolset SO. Accelerometer-determined physical activity and walking capacity in persons with Down syndrome, Williams syndrome and Prader-Willi syndrome. Res Dev Disabil. 2013;34(12):4395-403.

18. Pisacane A, Toscano E, Pirri I, Continisio P, Andria G, Zoli B, et al. Down syndrome and breastfeeding. Acta Paediatr. 2003;92(12):1479-81.

19. Flores-Lujano J, Perez-Saldivar ML, Fuentes-Panana EM, Gorodezky C, BernaldezRios R, Del Campo-Martinez MA, et al. Breastfeeding and early infection in the aetiology of childhood leukaemia in Down syndrome. Br J Cancer. 2009;101(5):8604.

20. Al-Sarheed M. Feeding habits of children with Down's syndrome living in Riyadh, Saudi Arabia. J Trop Pediatr. 2006;52(2):83-6.

21. Lewis E, Kritzinger A. Parental experiences of feeding problems in their infants with Down syndrome. Downs Syndr Res Pract. 2004;9(2):45-52.

22. Cullen EG, editor. Breastfeeding and Down syndrome: A Comprehensive Guide For Mothers and Medical Professionals Julia's Way; 2019. [Cited 2019 November 6]. Available from: https://juliasway.org/breastfeeding.

23. King G, Williams L, Hahn Goldberg S. Family-oriented services in pediatric rehabilitation: a scoping review and framework to promote parent and family wellness. Child Care Health Dev. 2017;43(3):334-47. 
24. Stanley MA, Shepherd N, Duvall N, Jenkinson SB, Jalou HE, Givan DC, et al. Clinical identification of feeding and swallowing disorders in 0-6 month old infants with Down syndrome. Am J Med Genet A. 2019;179(2):177-82.

25. Jackson A, Maybee J, Moran MK, Wolter-Warmerdam K, Hickey F. Clinical Characteristics of Dysphagia in Children with Down Syndrome. Dysphagia. 2016;31(5):663-71.

26. Genova L, Cerda J, Correa C, Vergara N, Lizama M. Good health indicators in children with Down syndrome: High frequency of exclusive breastfeeding at 6 months. Rev Chil Pediatr. 2018;89(1):32-41.

27. Mackman CA, Loomba RS, Slicker J, Bartz PJ. Growth Trajectory in Children with Trisomy 21 with and without Atrioventricular Septal Defect. Congenit Heart Dis. 2016;11(4):348-53.

28. O'Neill AC, Richter GT. Pharyngeal dysphagia in children with Down syndrome. Otolaryngol Head Neck Surg. 2013;149(1):146-50.

29. Jackson A, Maybee J, Wolter-Warmerdam K, DeBoer E, Hickey F. Associations between age, respiratory comorbidities, and dysphagia in infants with down syndrome. Pediatr Pulmonol. 2019.

30. Frank K, Esbensen AJ. Fine motor and self-care milestones for individuals with Down syndrome using a Retrospective Chart Review. J Intellect Disabil Res. 2015;59(8):719-29.

31. Ross CF, Bernhard CB, Smith-Simpson S. Parent-reported ease of eating foods of different textures in young children with Down syndrome. J Texture Stud. 2019.

32. Oliveira AC, Paiva SM, Martins MT, Torres CS, Pordeus IA. Prevalence and determinant factors of malocclusion in children with special needs. Eur J Orthod. 2011;33(4):413-8.

33. Bell EJ, Kaidonis J, Townsend GC. Tooth wear in children with Down syndrome. Aust Dent J. 2002;47(1):30-5.

34. Oliveira AC, Pordeus IA, Torres CS, Martins MT, Paiva SM. Feeding and nonnutritive sucking habits and prevalence of open bite and crossbite in children/adolescents with Down syndrome. Angle Orthod. 2010;80(4):748-53.

35. Faulks D, Mazille MN, Collado V, Veyrune JL, Hennequin M. Masticatory dysfunction in persons with Down's syndrome. Part 2: management. J Oral Rehabil. 2008;35(11):863-9. 
36. Osaili TM, Attlee A, Naveed H, Maklai H, Mahmoud M, Hamadeh N, et al. Physical Status and Parent-Child Feeding Behaviours in Children and Adolescents with Down Syndrome in The United Arab Emirates. Int J Environ Res Public Health. 2019;16(13).

37. van Dijk M, Lipke-Steenbeek W. Measuring feeding difficulties in toddlers with Down syndrome. Appetite. 2018;126:61-5.

38. O'Neill KL, Shults J, Stallings VA, Stettler N. Child-feeding practices in children with down syndrome and their siblings. J Pediatr. 2005;146(2):234-8.

39. Polfuss M, Simpson P, Neff Greenley R, Zhang L, Sawin KJ. Parental Feeding Behaviors and Weight-Related Concerns in Children With Special Needs. West J Nurs Res. 2017;39(8):1070-93.

40. Zemel BS, Pipan M, Stallings VA, Hall W, Schadt K, Freedman DS, et al. Growth Charts for Children With Down Syndrome in the United States. Pediatrics. 2015;136(5):e1204-11.

41. Mircher C, Briceno LG, Toulas J, Conte M, Tanguy ML, Cieuta-Walti C, et al. Growth curves for French people with Down syndrome from birth to 20 years of age. Am J Med Genet A. 2018;176(12):2685-94.

42. Tuysuz B, Goknar NT, Ozturk B. Growth charts of Turkish children with Down syndrome. Am J Med Genet A. 2012;158A(11):2656-64.

43. Van Gameren-Oosterom HB, Van Dommelen P, Oudesluys-Murphy AM, Buitendijk SE, Van Buuren S, Van Wouwe JP. Healthy growth in children with Down syndrome. PLoS One. 2012;7(2):e31079.

44. Su X, Lau JT, Yu CM, Chow CB, Lee LP, But BW, et al. Growth charts for Chinese Down syndrome children from birth to 14 years. Arch Dis Child. 2014;99(9):824-9.

45. Bertapelli F, Machado MR, Roso RD, Guerra-Junior G. Body mass index reference charts for individuals with Down syndrome aged 2-18 years. J Pediatr (Rio J). 2017;93(1):94-9.

46. Styles ME, Cole TJ, Dennis J, Preece MA. New cross sectional stature, weight, and head circumference references for Down's syndrome in the UK and Republic of Ireland. Arch Dis Child. 2002;87(2):104-8.

47. Sica CD, Cesa CC, Pellanda LC. Growth curves in Down syndrome with congenital heart disease. Rev Assoc Med Bras (1992). 2016;62(5):414-20. 
48. Samur San-Matin JE, Goncalves EM, Bertapelli F, Mendes RT, Guerra-Junior G. Body mass index cutoff point estimation as obesity diagnostic criteria in Down syndrome adolescents. Nutr Hosp. 2016;33(5):571.

49. Wendel D, Weber D, Leonard MB, Magge SN, Kelly A, Stallings VA, et al. Body composition estimation using skinfolds in children with and without health conditions affecting growth and body composition. Ann Hum Biol. 2017;44(2):108-20.

50. Goncalves Machado A, Lummertz Magenis M, Bongiolo AM, Castro K, da Silva MA, Schweigert Perry ID. Bioelectrical impedance analysis: body composition in children and adolescents with Down syndrome. Minerva Pediatr. 2017;69(6):560-3.

51. Tenenbaum A, Malkiel S, Wexler ID, Levy-Khademi F, Revel-Vilk S, Stepensky P. Anemia in children with down syndrome. Int J Pediatr. 2011;2011:813541.

52. Hart SJ, Zimmerman K, Linardic CM, Cannon S, Pastore A, Patsiogiannis V, et al. Detection of iron deficiency in children with Down syndrome. Genet Med. 2019.

53. Stagi S, Lapi E, Romano S, Bargiacchi S, Brambilla A, Giglio S, et al. Determinants of vitamin d levels in children and adolescents with down syndrome. Int J Endocrinol. 2015;2015:896758.

54. Polfuss M, Sawin KJ, Papanek PE, Bandini L, Forseth B, Moosreiner A, et al. Total energy expenditure and body composition of children with developmental disabilities. Disabil Health J. 2018;11(3):442-6.

55. Magenis ML, Machado AG, Bongiolo AM, Silva MAD, Castro K, Perry IDS. Dietary practices of children and adolescents with Down syndrome. J Intellect Disabil. 2018;22(2):125-34.

56. Samarkandy MM, Mohamed BA, Al-Hamdan AA. Nutritional assessment and obesity in Down syndrome children and their siblings in Saudi Arabia. Saudi Med J. 2012;33(11):1216-21.

57. Jankowicz-Szymanska A, Mikolajczyk E, Wojtanowski W. The effect of the degree of disability on nutritional status and flat feet in adolescents with Down syndrome. Res Dev Disabil. 2013;34(11):3686-90.

58. Jobling A, Cuskelly M. Young people with Down syndrome: a preliminary investigation of health knowledge and associated behaviours. J Intellect Dev Disabil. 2006;31(4):210-8.

59. Hinckson EA, Dickinson A, Water T, Sands M, Penman L. Physical activity, dietary habits and overall health in overweight and obese children and youth with intellectual disability or autism. Res Dev Disabil. 2013;34(4):1170-8. 
60. Curtin C, Bandini LG, Must A, Gleason J, Lividini K, Phillips S, et al. Parent support improves weight loss in adolescents and young adults with Down syndrome. J Pediatr. 2013;163(5):1402-8 e1.

61. Grammatikopoulou MG, Manai A, Tsigga M, Tsiligiroglou-Fachantidou A, GalliTsinopoulou A, Zakas A. Nutrient intake and anthropometry in children and adolescents with Down syndrome--a preliminary study. Dev Neurorehabil. 2008;11(4):260-7.

62. Lewanda AF, Gallegos MF, Summar M. Patterns of Dietary Supplement Use in Children with Down Syndrome. J Pediatr. 2018;201:100-5 e30.

63. Bathgate KE, Sherriff JL, Leonard H, Dhaliwal SS, Delp EJ, Boushey CJ, et al. Feasibility of Assessing Diet with a Mobile Food Record for Adolescents and Young Adults with Down Syndrome. Nutrients. 2017;9(3).

64. Polfuss M, Moosreiner A, Boushey CJ, Delp EJ, Zhu F. Technology-Based Dietary Assessment in Youth with and Without Developmental Disabilities. Nutrients. $2018 ; 10(10)$.

65. Reza SM, Rasool H, Mansour S, Abdollah H. Effects of calcium and training on the development of bone density in children with Down syndrome. Res Dev Disabil. 2013;34(12):4304-9.

66. Lima AS, Cardoso BR, Cozzolino SF. Nutritional status of zinc in children with Down syndrome. Biol Trace Elem Res. 2010;133(1):20-8.

67. Marques RC, de Sousa AF, do Monte SJ, Oliveira FE, do Nascimento Nogueira N, Marreiro DN. Zinc nutritional status in adolescents with Down syndrome. Biol Trace Elem Res. 2007;120(1-3):11-8.

68. Ellis JM, Tan HK, Gilbert RE, Muller DP, Henley W, Moy R, et al. Supplementation with antioxidants and folinic acid for children with Down's syndrome: randomised controlled trial. BMJ. 2008;336(7644):594-7.

69. Salman M. Systematic review of the effect of therapeutic dietary supplements and drugs on cognitive function in subjects with Down syndrome. Eur J Paediatr Neurol. 2002;6(4):213-9.

70. Blair CK, Roesler M, Xie Y, Gamis AS, Olshan AF, Heerema NA, et al. Vitamin supplement use among children with Down's syndrome and risk of leukaemia: a Children's Oncology Group (COG) study. Paediatr Perinat Epidemiol. 2008;22(3):288-95. 
71. Nisihara RM, Bonacin M, da Silva Kotze LM, de Oliveira NP, Utiyama S. Monitoring gluten-free diet in coeliac patients with Down's syndrome. J Hum Nutr Diet. 2014;27 Suppl 2:1-3. 
Table 1: Clinical features of DS with nutritional relevance

\begin{tabular}{|l|}
\hline Hypotonia \\
\hline Oropharyngeal abnormalities \\
\hline Gastrointestinal malformations and dysmotility \\
\hline Reduced growth rate \\
\hline Hypothyriodism \\
\hline Celiac disease \\
\hline Type 1 diabetes \\
\hline Intellectual disability \\
\hline Behavioural and psychiatric disorders \\
\hline
\end{tabular}

Table 2: Studies on nutritional intakes in children with Down syndrome

\begin{tabular}{|c|c|c|c|c|c|}
\hline & $\begin{array}{l}\text { Study } \\
\text { design }\end{array}$ & Age & Country & Method & Results \\
\hline Magenis et al (2018) & $\begin{array}{l}\text { Case- } \\
\text { control } \\
\text { (DS } n=19 \\
\text { and } \\
\text { controls } \\
n=19)\end{array}$ & $\begin{array}{l}5-18 \\
\text { years }\end{array}$ & Brazil & $\begin{array}{l}\text { Parent } \\
\text { completed } \\
\text { 3-day food } \\
\text { record }\end{array}$ & $\begin{array}{l}\text { In DS-group higher } \\
\text { intakes of energy, protein } \\
\text { and carbohydrates } \\
\text { compared to controls } \\
\text { Proportions with intakes } \\
\text { below RDA: } \\
\text { Vitamin D } 74 \% \text {, niacin } 21 \\
\% \text {, folate } 26 \% \text {, } \\
\text { pantothenic acid } 37 \% \text {, } \\
\text { calcium } 26 \% \text {, thiamin } 11 \\
\% \\
\text { Compared to controls no } \\
\text { significant difference in } \\
\text { proportions with } \\
\text { suboptimal intakes of } \\
\text { micronutrients }\end{array}$ \\
\hline $\begin{array}{l}\text { Samarkandy et al } \\
\text { (2012) }\end{array}$ & $\begin{array}{l}\text { Case- } \\
\text { control } \\
\text { (DS } n=108 \\
\text { Sibling } \\
\text { controls } \\
n=113 \text { ) }\end{array}$ & $\begin{array}{l}5-12 \\
\text { years }\end{array}$ & $\begin{array}{l}\text { Saudi } \\
\text { Arabia }\end{array}$ & $\begin{array}{l}\text { Parent } \\
\text { completed } \\
\text { 3-day food } \\
\text { record }\end{array}$ & $\begin{array}{l}\text { No significant difference } \\
\text { in energy intake between } \\
\text { children with DS and } \\
\text { siblings } \\
\text { Children with DS had } \\
\text { lower intakes of protein, } \\
\text { retinol, riboflavin, calcium } \\
\text { and potassium }\end{array}$ \\
\hline $\begin{array}{l}\text { Grammatikopoulou } \\
\text { et al (2008) }\end{array}$ & $\begin{array}{l}\text { Cross- } \\
\text { sectional } \\
(n=34)\end{array}$ & $\begin{array}{l}2-18 \\
\text { years }\end{array}$ & Greece & $\begin{array}{l}\text { Parent } \\
\text { completed } \\
\text { 3-day food } \\
\text { record }\end{array}$ & $\begin{array}{l}\text { Children } 2-9 \text { years }(n=11) \\
\text { was compared to } \\
\text { adolescents } 10-18 \text { years } \\
(n=23) \text { and as expected } \\
\text { highest intakes in total } \\
\text { energy and }\end{array}$ \\
\hline
\end{tabular}




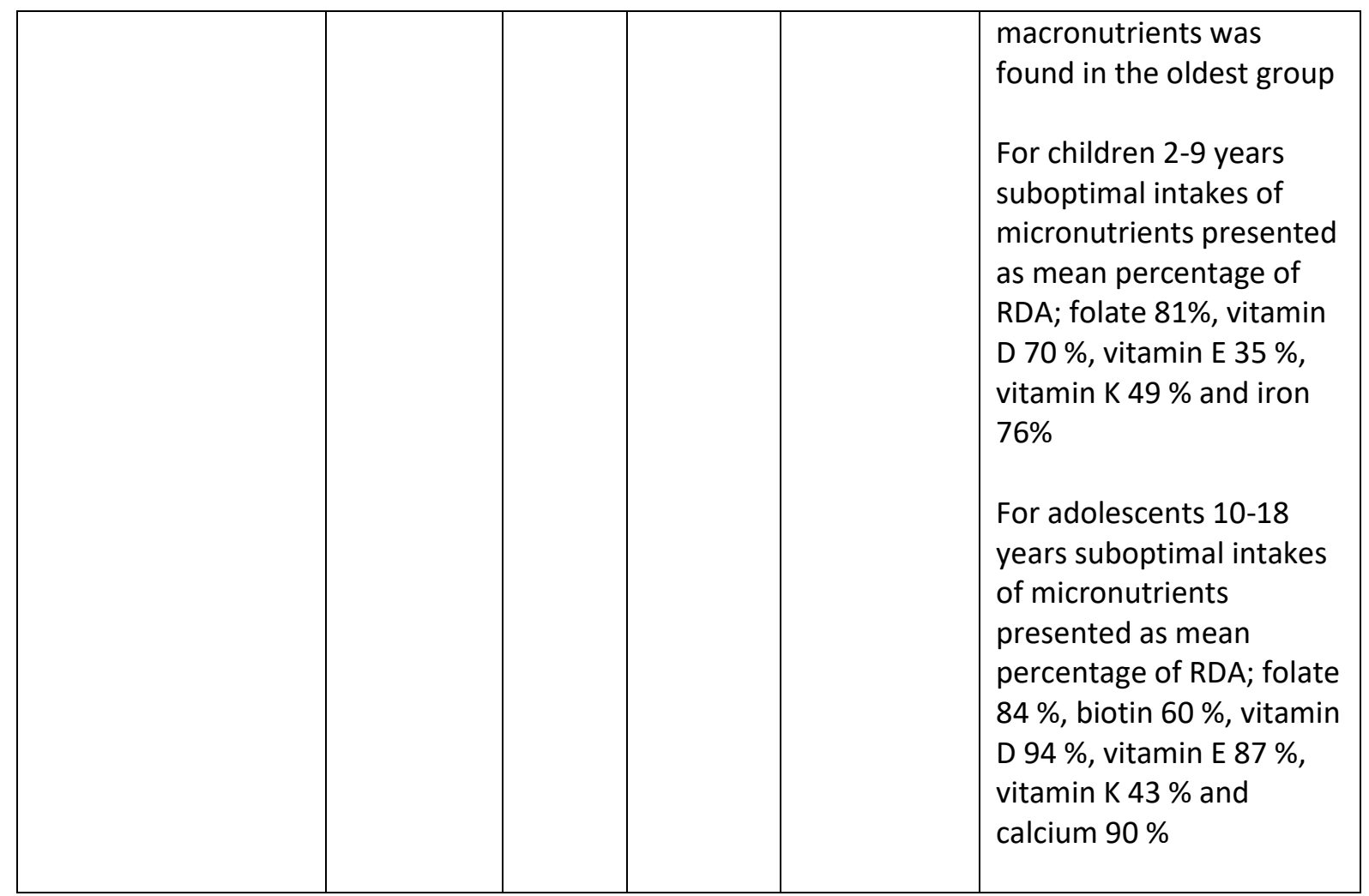

$\mathrm{BMI}=$ Body mass index

$\mathrm{RDA}=$ Recommended dietary allowances

Table 3: Dietary intervention studies in children with Down syndrome

\begin{tabular}{|c|c|c|c|c|c|}
\hline & Study design & Age & Country & Method & Results \\
\hline $\begin{array}{l}\text { Parisotto et } \\
\text { al (2014) }\end{array}$ & $\begin{array}{l}\text { Case-control } \\
\text { (DS } n=21 \\
\text { controls } n=18 \text { ) }\end{array}$ & $\begin{array}{l}3-14 \\
\text { years }\end{array}$ & Brazil & $\begin{array}{l}\text { Measurements of } \\
\text { antioxidant } \\
\text { enzymatic activity } \\
\text { from whole blood, } \\
\text { hemolysates and in } \\
\text { serum samples } \\
\text { 6-months } \\
\text { intervention only in } \\
\text { the DS-group with } \\
\text { daily supplement of } \\
\text { antioxidants: vitamin } \\
\text { E } 400 \text { mg, vitamin C } \\
500 \mathrm{mg}\end{array}$ & $\begin{array}{l}\text { Differences in antioxidant } \\
\text { enzymatic activity was } \\
\text { found between persons } \\
\text { with DS and controls } \\
\text { More normalized } \\
\text { antioxidant enzymatic } \\
\text { activity values were } \\
\text { described in children with } \\
\text { DS after intervention. } \\
\text { Increased vitamin E levels in } \\
\text { whole blood of children } \\
\text { with DS after intervention }\end{array}$ \\
\hline $\begin{array}{l}\text { Lakshmi et } \\
\text { al (2008) }\end{array}$ & $\begin{array}{l}\text { Case-Control } \\
\text { (DS } n=40 \\
\text { Controls } n=40 \text { ) }\end{array}$ & $\begin{array}{l}5-16 \\
\text { years }\end{array}$ & India & $\begin{array}{l}\text { Serum measurement } \\
\text { of } \\
\text { acetylcholinesterase } \\
\text { and } \\
\text { butyrylcholinesterase }\end{array}$ & $\begin{array}{l}\text { The values of } \\
\text { acetylcholinesterase and } \\
\text { butyrylcholinesterase was } \\
\text { reduced in children with DS } \\
\text { compared to controls } \\
\text { before intervention }\end{array}$ \\
\hline
\end{tabular}




\begin{tabular}{|c|c|c|c|c|c|}
\hline & & & & $\begin{array}{l}\text { 6-months } \\
\text { intervention only in } \\
\text { the DS-group with } \\
\text { daily supplements of: } \\
\text { Zinc } 1 \mathrm{mg} / \mathrm{kg} \text { body } \\
\text { weight, vitamin A } 1.5 \\
\mathrm{mg} \text {, vitamin E } 17 \mathrm{mg} \text {, } \\
\text { ascorbic acid } 100 \mathrm{mg} \text {, } \\
\text { thiamine } 10 \mathrm{mg} \text {, } \\
\text { riboflavin } 10 \mathrm{mg} \text {, } \\
\text { phyroxidine } \\
\text { hydrochloride } 3 \mathrm{mg} \text {, } \\
\text { cyanocobalamin } 5 \mu \mathrm{g} \text {, } \\
\text { niacin } 50 \mathrm{mg} \text {, folate } 1 \\
\text { mg, calcium } \\
\text { phantothenate } 12.5 \\
\text { mg, copper } 2.5 \mathrm{mg} \text {, } \\
\text { selenium } 60 \mu \mathrm{gg} \\
\text { manganese } 1.4 \mathrm{mg} \\
\text { and chromium } 5 \mu \mathrm{g}\end{array}$ & $\begin{array}{l}\text { These measures were } \\
\text { increased and almost } \\
\text { normalized after } \\
\text { intervention }\end{array}$ \\
\hline $\begin{array}{l}\text { Ellis et al } \\
(2008)\end{array}$ & $\begin{array}{l}\text { Four-armed } \\
\text { single-blinded } \\
\text { randomized } \\
\text { controlled trial } \\
\text { (In total } n=156) \\
\text { A: Antioxidants } \\
\text { and folate }(n=41) \\
\text { B: Antioxidants } \\
(n=40) \\
\text { C: Folate }(n=36) \\
\text { D: Placebo } \\
(n=39)\end{array}$ & $\begin{array}{l}\text { Infants < } \\
7 \text { months }\end{array}$ & $\begin{array}{l}\text { United } \\
\text { Kingdom }\end{array}$ & $\begin{array}{l}\text { 18-months } \\
\text { intervention study } \\
\text { Antioxidants: } \\
\text { Selenium } 10 \mu \text {, zinc } \\
5 \mathrm{mg} \text {, vitamin A } 0.9 \\
\text { mg, vitamin E } 100 \mathrm{mg} \\
\text { and vitamin C } 50 \mathrm{mg} \\
\text { Folate: } 0.1 \mathrm{mg} \\
\text { Clinical } \\
\text { improvements were } \\
\text { measured with } \\
\text { quotient on Griffiths } \\
\text { mental } \\
\text { developmental scale } \\
\text { and MacArthur } \\
\text { communicative } \\
\text { development } \\
\text { inventory } \\
\text { Measurements of } \\
\text { activity in antioxidant } \\
\text { enzymes in red blood } \\
\text { cells and biomarker } \\
\text { of lipid peroxidation } \\
\text { in urine }\end{array}$ & $\begin{array}{l}\text { No evidence of clinically or } \\
\text { statistically significant } \\
\text { effects of antioxidants or } \\
\text { folate on any of the } \\
\text { outcomes measured }\end{array}$ \\
\hline $\begin{array}{l}\text { Nachvak et } \\
\text { al (2004) }\end{array}$ & $\begin{array}{l}\text { Three-armed } \\
\text { randomized } \\
\text { controlled trial } \\
\text { (DS } n=93, \text { sibling } \\
\text { controls } n=26) \\
\end{array}$ & $\begin{array}{l}7-15 \\
\text { years }\end{array}$ & Iran & $\begin{array}{l}\text { Measurements of } \\
\text { oxidative stress } \\
\text { markers: serum } \\
\text { thiobarbitubic acid } \\
\text { reactive substances }\end{array}$ & $\begin{array}{l}\text { Higher levels of oxidative } \\
\text { stress markers were found } \\
\text { in children with DS } \\
\text { compared to their siblings }\end{array}$ \\
\hline
\end{tabular}




\begin{tabular}{|c|c|c|c|c|c|}
\hline & $\begin{array}{l}\text { A: } \alpha \text {-tocopherol } \\
\text { B: } \alpha \text {-lipoic acid } \\
\text { C: Placebo }\end{array}$ & & & $\begin{array}{l}\text { (TBARS) and urinary } \\
\text { 8-hydroxy-2- } \\
\text { deoxyguanosine } \\
\text { (8OHdG) } \\
\text { 4-months } \\
\text { intervention only in } \\
\text { DS-group } \\
\text { A: } \alpha \text {-tocopherol: } 268 \\
\text { mg/day } \\
\text { B: } \alpha \text {-lipoic acid: } 100 \\
\text { mg/day }\end{array}$ & $\begin{array}{l}\text { No change in TBARS from } \\
\text { any intervention. } \\
\text { Significant decrease in } \\
\text { urinary } 80 \mathrm{OHG} \text { in } \alpha \text { - } \\
\text { tocopherol-group } \\
\text { compared to placebo }\end{array}$ \\
\hline $\begin{array}{l}\text { Marreiro et } \\
\text { al (2009) }\end{array}$ & $\begin{array}{l}\text { Uncontrolled } \\
\text { intervention } \\
\text { study } \\
(\mathrm{DS} n=16)\end{array}$ & $\begin{array}{l}10-19 \\
\text { years }\end{array}$ & Brazil & $\begin{array}{l}\text { 4-week intervention } \\
\text { with daily } 30 \text { mg zinc } \\
\text { supplementation } \\
\text { Zinc related } \\
\text { nutritional status } \\
\text { was evaluated by } \\
\text { measures in plasma } \\
\text { and erythrocytes } \\
\text { Measurement of } \\
\text { serum concentration } \\
\text { of thyroid hormones } \\
\left(\mathrm{T}_{4} \text { and } \mathrm{T}_{3}\right) \text {. }\end{array}$ & $\begin{array}{l}\text { Increased concentration of } \\
\text { zinc in plasma and reduced } \\
\text { in erythrocytes after } \\
\text { intervention } \\
\text { No difference in serum } \\
\text { concentration of thyroid } \\
\text { hormones }\end{array}$ \\
\hline $\begin{array}{l}\text { Gualandri et } \\
\text { al (2003) }\end{array}$ & $\begin{array}{l}\text { Uncontrolled } \\
\text { intervention } \\
\text { study } \\
(\mathrm{DS} n=33)\end{array}$ & $\begin{array}{l}1-14 \\
\text { years }\end{array}$ & Italy & $\begin{array}{l}\text { In children with } \\
\text { compromised redox } \\
\text { balance at baseline } \\
\text { 30-day intervention } \\
\text { with daily } \\
\text { supplementation: } \\
\alpha \text {-lipoic acid } 200 \mathrm{mg} \\
\text { and } \\
\text { L-cysteine } 200 \mathrm{mg} \\
\text { Measurement of } \\
\text { thiol groups, septic } \\
\text { reactive oxygen } \\
\text { species (ROS) and } \\
\text { total antioxidant } \\
\text { status in serum }\end{array}$ & $\begin{array}{l}\text { Thirteen persons dropped- } \\
\text { out and results are based } \\
\text { on assessment of } 20 \\
\text { individuals } \\
\text { Significant increase in } \\
\text { serum thiol groups and } \\
\text { antioxidant capacity in } \\
\text { serum } \\
\text { Significant decrease in } \\
\text { serum total and septic ROS }\end{array}$ \\
\hline $\begin{array}{l}\text { Reza et al } \\
\text { (2013) }\end{array}$ & $\begin{array}{l}\text { Four-armed } \\
\text { randomized } \\
\text { controlled trial } \\
\text { (DS } n=48 \text { ) } \\
\text { A: Exercise and } \\
\text { calcium } \\
\text { B: Calcium } \\
\text { C: Exercise }\end{array}$ & $\begin{array}{l}7-12 \\
\text { years }\end{array}$ & Iran & $\begin{array}{l}\text { 4-months } \\
\text { intervention } \\
\text { Exercise: } 45 \text { min } \\
\text { weight-bearing } \\
\text { activities } 3 \text { times per } \\
\text { week } \\
\text { Calcium: Daily intake } \\
\text { of } 500 \mathrm{ml} \text { vitamin D } \\
\text { enriched cow milk. }\end{array}$ & $\begin{array}{l}\text { At baseline all groups had } \\
\text { approximately } 430 \mathrm{mg} / \mathrm{day} \\
\text { dietary intake of calcium } \\
\text { and similar physical activity } \\
\text { pattern } \\
\text { Post intervention all groups } \\
\text { had significant higher BMD. }\end{array}$ \\
\hline
\end{tabular}




\begin{tabular}{|c|c|c|c|c|c|}
\hline & $\begin{array}{l}\text { D: No } \\
\text { intervention }\end{array}$ & & & $\begin{array}{l}\text { Containing } 200 \\
\text { mg/day calcium. } \\
\text { Measurement by } \\
\text { DXA of bone mineral } \\
\text { density (BMD) at } \\
\text { right proximal femur } \\
\text { neck }\end{array}$ & $\begin{array}{l}\text { Combined exercise and } \\
\text { calcium group; } 14.6 \% \\
\text { increase, exercise-group } 8.6 \\
\% \text { increase, calcium-group } \\
3.5 \% \text { increase, no } \\
\text { intervention } 1.3 \% \text { increase }\end{array}$ \\
\hline $\begin{array}{l}\text { Stagi et al } \\
(2015)\end{array}$ & $\begin{array}{l}\text { Controlled } \\
\text { intervention } \\
\text { study } \\
\text { (DS } n=31 \text {, } \\
\text { controls } n=99 \text { ) }\end{array}$ & $\begin{array}{l}4-19 \\
\text { years }\end{array}$ & Italy & $\begin{array}{l}\text { Measured plasma } \\
25(\mathrm{OH}) \mathrm{D} \text { levels, } \\
\text { serum calcium, and } \\
\text { phosphate, bone } \\
\text { specific alkaline } \\
\text { phosphate, } \\
\text { parathyroid hormone } \\
\text { Evaluation of dietary } \\
\text { vitamin } \mathrm{D} \text { intake by } \\
\text { parent interview on } \\
\text { use of vitamin } \mathrm{D} \\
\text { fortified milk } \\
\text { Intervention: Oral } \\
\text { daily } 10 \mu \mathrm{g} \text { vitamin } \\
\text { D3 supplement from } \\
\text { November through } \\
\text { May }\end{array}$ & $\begin{array}{l}\text { At baseline } \\
25(\mathrm{OH}) \mathrm{D} \text { levels were } \\
\text { significant reduced in DS } \\
\text { group. In DS } 45 \% \text { showed } \\
\text { deficient levels ( }<20 \mathrm{ng} / \mathrm{mL} \text { ) } \\
\text { and } 32 \% \text { severe deficiency } \\
\text { ( } \leq 10 \mathrm{ng} / \mathrm{mL} \text { ) } \\
\text { Elevated PTH levels in DS- } \\
\text { group compared to controls } \\
\text { Children with DS consume } \\
\text { less vitamin D fortified milk } \\
\text { After intervention } \\
\text { Increased } 25(\mathrm{OH}) \text { D plasma } \\
\text { levels in DS-group but not } \\
\text { controls and in DS-group } \\
\text { still significantly reduced } \\
\text { compared to controls. } \\
\text { In DS } 29 \% \text { showed } \\
\text { deficient } 25(O H) \text { D level and } \\
22 \% \text { severe deficiency } \\
\text { DS-group still higher levels } \\
\text { of PTH compared to } \\
\text { controls }\end{array}$ \\
\hline
\end{tabular}


Figure

\section{Suggested nutritional assessment in children with Down syndrome}

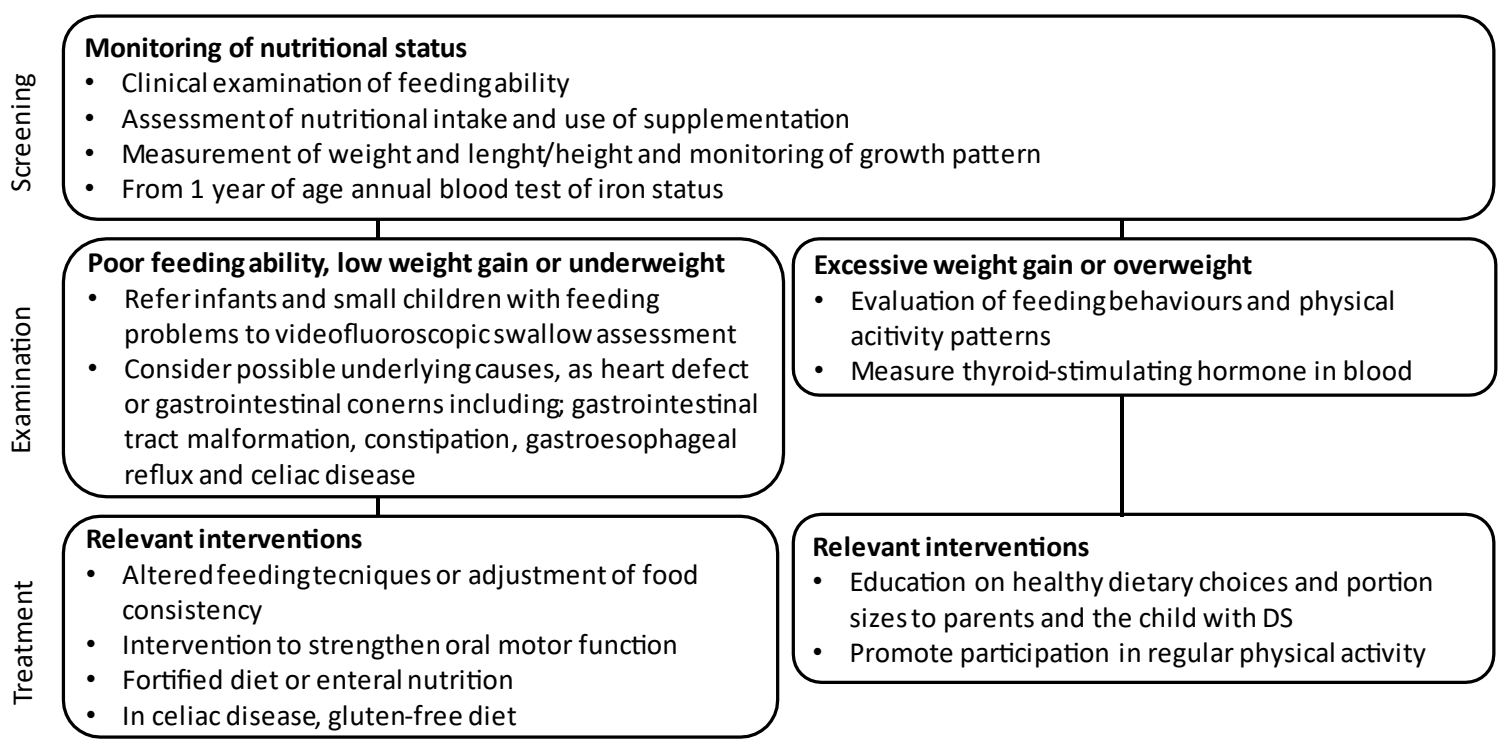

